\title{
Evidence for high inter-generational individual quality in yellow-eyed penguins
}

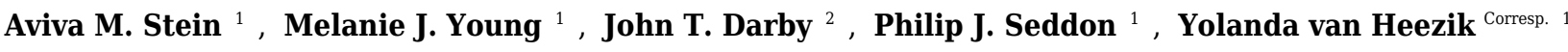 \\ 1 Zoology Department, University of Otago, Dunedin, New Zealand \\ 2 Otago Museum, Dunedin, New Zealand \\ Corresponding Author: Yolanda van Heezik \\ Email address: yolanda.vanheezik@otago.ac.nz
}

Longitudinal studies focusing on lifetime reproductive success (LRS) have been used to measure individual breeding performance and identify commonalities among successful breeders. By extending the focus to subsequent generations we identify a proportion of high-quality individuals that contribute disproportionately to the population over multiple generations. We used 23 years of yellow-eyed penguin (Megadyptes antipodes) breeding data from one breeding area to identify the proportion of individual birds that raised successful breeders, which in turn raised offspring. We explored which life-history components influenced lifetime reproductive success, as this knowledge would enable conservation resources to be focused on high-performing individuals in this endangered population. From 2147 birds marked as chicks, 370 (17.2\%) survived to adulthood and recruited to their natal location, of which 219 (10.2\%) fledged offspring: 124 (56.6\%) of the 219 birds produced offspring that recruited as breeders. Only 102 birds (4.8\% of 2147) fledged first-generation offspring that in turn fledged offspring (second-generation offspring, or grand-offspring). We found that c. $25 \%$ of the birds that survived to breed had above-average LRS as well as above-average numbers of grand-offspring, and were more likely to have produced first-generation chicks that recruited and also produced aboveaverage numbers of second-generation chicks. Our findings suggest that there is a core of "super-breeders" that contribute disproportionately to the population over successive generations. Lifespan and age-at-first-breeding were correlated with LRS. We suggest that traits of birds relating to longevity, health (e.g. immunocompetence) and fitness could be examined to identify potential links with high LRS and inter-generational fecundity. "Superbreeders" appear to consistently achieve high LRS and long lifespans in a stochastic environment, demonstrating greater resilience in the face of extreme events. 


\section{Evidence for high inter-generational individual quality in yellow-eyed 2 penguins}

3

4 Aviva M. Stein, ${ }^{1}$ Melanie J. Young, ${ }^{1}$ John T. Darby, ${ }^{2}$ Philip J. Seddon, ${ }^{1}$ Yolanda van Heezik ${ }^{1 *}$

$5{ }^{1}$ Zoology Department, University of Otago, P.O. Box 56, Dunedin, 9054, New Zealand.

$6 \quad$ 2Otago Museum, 419 Great King Street, Dunedin 9016, New Zealand.

7

8 *Corresponding author: Email: yolanda.vanheezik@otago.ac.nz, Telephone: +64 34794107 


\section{ABSTRACT}

10 Longitudinal studies focusing on lifetime reproductive success (LRS) have been used to measure

11 individual breeding performance and identify commonalities among successful breeders. By

12 extending the focus to subsequent generations we identify a proportion of high-quality

13 individuals that contribute disproportionately to the population over multiple generations. We

14 used 23 years of yellow-eyed penguin (Megadyptes antipodes) breeding data from one breeding

15 area to identify the proportion of individual birds that raised successful breeders, which in turn

16 raised offspring. We explored which life-history components influenced lifetime reproductive

17 success, as this knowledge would enable conservation resources to be focused on high-

18 performing individuals in this endangered population. From 2147 birds marked as chicks, 370

$19(17.2 \%)$ survived to adulthood and recruited to their natal location, of which $219(10.2 \%)$

20 fledged offspring: 124 (56.6\%) of the 219 birds produced offspring that recruited as breeders.

21 Only 102 birds (4.8\% of 2147) fledged first-generation offspring that in turn fledged offspring

22 (second-generation offspring, or grand-offspring). We found that c. $25 \%$ of the birds that

23 survived to breed had above-average LRS as well as above-average numbers of grand-offspring,

24 and were more likely to have produced first-generation chicks that recruited and also produced

25 above-average numbers of second-generation chicks. Our findings suggest that there is a core of

26 "super-breeders" that contribute disproportionately to the population over successive

27 generations. Lifespan and age-at-first-breeding were correlated with LRS. We suggest that traits

28 of birds relating to longevity, health (e.g. immunocompetence) and fitness could be examined to

29 identify potential links with high LRS and inter-generational fecundity. "Super-breeders" appear

30 to consistently achieve high LRS and long lifespans in a stochastic environment, demonstrating

31 greater resilience in the face of extreme events. 


\section{INTRODUCTION}

35 Unlike cross-sectional studies across one or two breeding seasons, longitudinal studies based on

36 lifetime reproductive success (LRS) average out occasional breeding failures, and increase the

37 accuracy of measurement of individual success (Krüger \& Lindström, 2001). The collection of

38 long-term life-history data from a population of marked individuals makes it possible to identify

39 the proportion of animals that produce recruits, enabling conservation efforts to be efficiently

40 focused on individuals with successful traits (Moreno, 2003). Moreover, the overall contribution

41 of individuals with different lifespans or reproductive strategies to subsequent generations can be

42 compared (Clutton-Brock, 1988; Newton, 1989; Wooller, Bradley \& Croxall, 1992; Brommer,

43 Pietiäinen \& Kolunen 1998).

of fledglings from a given population will die before sexual maturity (Bryant, 1979; Newton, 1989); not all individuals that attempt to breed will be successful; and successful individuals vary

47 in their productivity (Newton, 1989). The LRS distribution of a population is typically highly skewed, with large numbers of individuals producing small numbers of young, and only a small proportion of adults producing large numbers of young (Clutton-Brock, 1988, Newton, 1989). Specific life-history and reproductive traits can be indicative of LRS. Lifespan is the strongest

51 correlate, with longer-lived individuals commonly achieving a higher LRS (Gustafsson, 1986;

52 Clutton-Brock, 1988; Newton, 1989). In seabirds, where individuals can start breeding at various

53 ages, variance in LRS is largely related to variation in breeding lifespan (Moreno, 2003), because

54 an increased number of breeding seasons allows individuals more opportunities to successfully 55 fledge offspring. 
If only a small proportion of individuals maintain most of the population, the

57 identification of traits affecting lifetime reproductive success of an individual are relevant for conservation efforts. Resources can be diverted towards protecting particularly productive individuals at times when the population is assailed by environmental challenges such as adverse climate conditions, reduced food availability, disease outbreaks, or catastrophic events (e.g. oil spills, Gartrell et al., 2013). In the case of a pest species, culling efforts could be focused on these highly productive individuals (Moreno, 2003). each other include age, experience, pair bond duration, health condition, sex, number of mates, mate fidelity and site fidelity (Ryder ,1980; Clutton-Brock, 1988; Gavin \& Bollinger, 1988; Bradley et al., 1990; Wooller et al., 1990; Chastel, Weimerskirch \& Jouventin, 1995). For example, in long-lived seabird species, a period of poor reproductive success at a young age or at a lower level of experience may be superseded by a period at which the individual performs at their peak reproductive output (Forslund \& Pärt, 1995). At an older age, senescence may begin to reduce reproductive output, followed by terminal illness and death (Fowler, 1995; Nisbet \& Dann, 2009; Froy et al., 2013). With increasing age, maternal efficiency might allow for control

72 of the timing, size, volume, composition and pore density of eggs, and high levels of pair

73 synchrony through maintenance of long-term pair bonds may reduce incubation periods and

74 increase nesting success (Massaro et al., 2002; Massaro et al., 2004). Breeding skills may

75 therefore improve with both age and experience, as well as with improved synchrony between

76 mated pairs (Forslund \& Pärt, 1995). The relative importance of each of these factors in

77 estimating LRS is difficult to assess, and can differ dramatically between species and geographic 78 locations. 

others because they have better skills. State-based assessment of individual breeder quality often requires the assumption or prediction that a component of the individual's health or skill within that system is a driving factor determining its reproductive success (Wendeln \& Becker, 1999; Moreno, 2003), and that this superior skill is independent of age-related performance. These state-based qualities and their relationship with breeding success and LRS can be highly variable within a population of seabirds, but might have low variation for individual birds over time (e.g. common terns Sterna hirundo, Wendeln \& Becker, 1999). Breeding seabirds have a range of responses to catastrophic climatic or weather events, e.g. El Niño Southern Oscillation (ENSO) (Boersma, 1978), and vary in the rate at which food is delivered to chicks (Ens et al., 1992).

Territoriality also can be associated with: individual quality in relation to nesting density (Stokes \& Boersma, 2000); nest site characteristics (Stokes \& Boersma, 1998); and rank dominance

91 (Schubert et al., 2007). consider the viability of those offspring. There may be variability in the quality of offspring produced by different individuals that further reduces the proportion of individuals contributing to subsequent generations. By using a 23-year dataset of individually-tracked yellow-eyed penguins we were able to follow reproductive success over more than one generation and identify the proportion of a penguin population that produces grand-offspring. Yellow-eyed penguins (hōiho, Megadyptes antipodes) are endemic to New Zealand and listed as 'endangered' on the IUCN Red List (Birdlife International, 2015). Some mainland populations are intensively managed to mitigate threats posed by introduced predators, disturbance and habitat destruction

101 (McKinlay, 2001). Because yellow-eyed penguins are sedentary (Seddon, van Heezik \& 
102 Ellenberg, 2013), long-lived, have high natal philopatry, high breeding site fidelity once

103 breeding, and are monogamous (Richdale, 1957), they are an ideal species to study LRS. We

104 investigated: (1) the proportion of birds that survive to adulthood; (2) the proportion of adults

105 that breed; (3) the proportion of breeders that produce young that recruit to the breeding

106 population (first-generation); and (4) the proportion of adults producing grand-offspring (second-

107 generation). We also explored the characteristics of highly successful breeders, and the

108 relationship of this trait between generations. We predicted that in line with other seabird

109 species, only a small proportion of yellow-eyed penguins would survive to adulthood, breed, and

110 produce young, and that differences in LRS between males and females exist due to the

111 difference in age-at-first-breeding, with females known to begin breeding earlier than males

112 (Richdale, 1957; Darby \& Seddon, 1990). We predicted that lifespan would have the greatest

113 influence on the number of offspring produced, and be positively correlated with LRS. Yellow-

114 eyed penguins with earlier age-at-first-breeding and fewer overall mates were predicted to have 115 greater LRS.

\section{METHODS}

117 Yellow-eyed penguins are solitary breeders, in contrast with most other penguin species and 118 seabirds that breed colonially (Richdale, 1957; Darby \& Seddon, 1990). In September-October 119 clutches of up to two eggs are laid, and chicks fledge at c. 106 days from late January to late

120 February (Richdale, 1957; Seddon \& Davis, 1989; Darby \& Seddon, 1990).

\section{Yellow-eyed Penguin Database}

122 We obtained breeding data from the Yellow-eyed Penguin Database administered by the New

123 Zealand Department of Conservation (DOC) and accessed through a Memorandum of

124 Understanding between DOC, representing the contributors to the database, and the University of 
125 Otago. We analysed only data from yellow-eyed penguins breeding at the Boulder Beach

126 complex on the Otago Peninsula, New Zealand, (45 $500 \mathrm{~S}$ and $170^{\circ} 300 \mathrm{E}$; Fig. 1) because it

127 supports a relatively large population of yellow-eyed penguins, has an inter-decadal history of

128 intensive monitoring and it has been trapped for introduced predators over time. This site has the

129 longest history of chick marking, with the majority of chicks fledged at this site marked with a

130 stainless steel flipper band issued by the New Zealand National Bird Banding Scheme (NZBBS).

131 We acknowledge that the use of flipper bands might present bias (sensu Petersen et al., 2005),

132 however in contrast to the foraging ranges of penguin species for which negative impacts of

133 flipper bands have been identified, yellow-eyed penguins are inshore foragers and have much

134 shorter foraging trips (van Heezik \& Seddon, 1990; Mattern et al., 2007). Consequently impacts

135 of flipper bands are likely to be minimal. While negative impacts have been documented for

136 some penguin species (e.g. king penguins, Aptenodytes patagonicus, Gauthier-Clerc et al.

137 (2004); Adélie penguins, Pygoscelis adeliae, Dugger et al. 2006; little penguins, Eudyptula

138 minor, Hoskins et al. 2008), impacts have been negligible for others (e.g. African penguins,

139 Spheniscus demersus, Barham et al. 2008; Hampton et al. 2009; magellanic penguins, $S$.

140 magellanicus, Boersma and Rebstock 2009). A separate study analysing the impact of research

141 manipulations found that even a double banding study on yellow-eyed penguins in one season

142 had no effect on productivity or subsequent survival (Seddon, van Heezik \& Ellenberg, 2013).

143 Before commencing this study, we completed a comprehensive error check, which involved

144 checking the original notebook records against electronic database records to ensure a high level 145 of accuracy and consistency.

146 Data for survival to adulthood and breeding 
147 A total of 2147 birds were marked at Boulder Beach as chicks or juveniles between 1981 and

148 2003. We used this sample to calculate the proportion of birds that survived post-fledging, to

149 adulthood (defined as reaching two years of age, when sexually mature), the proportion that

150 recruited to Boulder Beach and attempted to breed, fledged offspring, fledged offspring that

151 survived to adulthood and recruited to the breeding population, and fledged offspring (first-

152 generation) that in turn successfully bred and produced offspring (second-generation, or grand-

153 chicks). Birds from cohorts 1981-2003 that were still alive or had been sighted after 2007 were

154 excluded from the sample as their breeding lifetime had not ended ( $\mathrm{n}=73 \mathrm{birds})$.

\section{Data for LRS analyses}

156 For the detailed analysis of life-history and lifetime reproductive success we used a subset of the

157 data which included information on 130 "founding generation" birds of known sex that survived

158 to breed at least once, from the 1981 to 2003 cohorts, as we considered sex to be an important

159 factor, but sexing information was not always available. We excluded birds whose parents were

160 included in the data subset to avoid pseudoreplication $(n=87$ birds). We chose the year 2003 as

161 the cut-off cohort, since mean age at first breeding is between three and four years (Richdale,

162 1957): this allowed for birds to have complete lifespans by age 4 in 2007, breed, have offspring

163 that survived to breed (up to 2011) and grand offspring that survived up until the 2014/15

164 breeding season, when these data were last updated. We did not include birds beyond the 2003

165 cohort, or birds that were alive after 2007, so that we were sure that all of their surviving

166 offspring had recruited to breed by 2014 .. The latest year a bird with a complete life history

167 could be recorded as breeding at least once, and be presumed dead was 2007 (i.e. birds from the

1682003 cohort would have had a complete lifespan of 4 years to meet the study's parameters). We

169 excluded birds if they were marked before the 1981 cohort when intensive monitoring began. 
170 We defined LRS as the number of offspring produced by an individual over their lifetime.

171 Only data recorded from birds marked as chicks or as juveniles (one-year olds) could be used to

172 ensure complete life-histories, as they were of known age due to plumage differences (duller

173 colouration and lack of the distinctive yellow eye and crown of the adults). Yellow-eyed

174 penguins are typically marked at c. 80 - 90 days, before fledging at $c .106$ days (Seddon et al.,

175 2013). If a bird was marked as a juvenile, we estimated the cohort year by subtracting one year.

176 A bird was considered to have attempted to breed if it or its mate laid an egg.

177 Analysis of LRS requires complete detectability of the focal population: this would be

178 compromised if individuals bred elsewhere, or skipped breeding years and were consequently

179 recorded as having died. We are confident that we have full records of birds due to the intensive

180 monitoring at the study site and annual monitoring at adjacent sites along the coast, and the high

181 level of natal (c. 81\%) and breeding philopatry (c. 98\%), and monogamy exhibited by this

182 species (Richdale, 1957; Ratz et al., 2004). Birds that skip breeding remain largely undetectable

183 during the breeding season, with only c. 8\% of skipped birds in our sample being resighted as a

184 non-breeder, however detection of breeders is close to 100\% (Hegg et al., 2012). In our sample,

18553 yellow-eyed penguins that survived to breed skipped at least one breeding season once they

186 had established breeding, which is not uncommon, particularly in the year following a poor

187 season, death of a mate or a divorce (Moore, 1994; Ratz et al., 2004; Setiawan et al., 2005). Due

188 to the small, discrete size of nesting areas, the intensity of monitoring at this and in surrounding

189 sites, and the high degree of breeding site fidelity, we assumed that if a bird or breeding pair

190 were not seen during multiple visits to the breeding area and to other surrounding areas from

191 early incubation to the end of the guard period they were undertaking a breeding skip. None of 
192 the birds we assumed to be undertaking a breeding skip were re-sighted at adjacent monitored

193 breeding areas during their skipped year.

\section{Sample parameters}

195 The sample parameters for modelling life-history included sex, total number of breeding

196 attempts, recruitment of first-generation offspring, recruitment of successful first-generation

197 offspring, age-at-first-breeding, breeding lifespan, total number of mates and lifespan. We did

198 not include 'Cohort' as a factor because the longer-lived birds in later cohorts had not completed

199 their breeding lifetimes, unlike shorter-lived birds. Therefore including cohort would give a false

200 impression that the super breeder phenomenon ceased at 1994. To ensure that cohort was not an

201 important variable we ran a modified model on a subset of the total data set - the birds from

202 cohorts 1981 - 1994, which included both short-lived and long-lived birds for which we had full

203 LRS $(\mathrm{n}=161)$, and found no strong effects (Suppl. Material S2, T2).

Birds were sexed by adult head and foot measurements according to Setiawan, Darby \&

205 Lambert (2004). In instances where birds had never been measured or when fledgling

206 measurements were analysed, we inferred the sex from mates where possible, on the assumption

207 that pairings were between males and females only and that the mate had been correctly

208 identified. If there were no measurements or sex recorded for mates, we removed these birds

209 from any lifetime data analysis. We limited our sample for the analysis of life-history traits

210 affecting LRS to birds that survived to breed from the original sample of 2147 birds, that we

211 were able to sex, and we excluded their offspring ("founding generation", females $\mathrm{n}=62$, and

212 males $n=68$ ), so as not to pseudoreplicate breeding pairs, or parents and their offspring.

213 We measured lifespan in whole years at the time of marking as chicks (c. 3 months old),

214 to the time of either being found dead or 'missing' after three consecutive years. Age-at-first- 
215 breeding was recorded as the age of the bird during its first recorded breeding attempt. We

216 calculated the number of mates as the minimum possible number of mates, due to 60 of 130 birds

217 in the sample having unidentified mates in some years. We assumed that if a bird's mate was not

218 recorded but it was breeding with a particular bird in the previous and subsequent years that it

219 was the same mate in all three seasons.

\section{Statistical analysis}

221 We carried out all statistical analyses using R (Version 3.3.1, R Core Team 2016). We used two-

222 sample Wilcoxon rank-sum tests to test for statistical significance between males and females,

223 for parameters including LRS, age-at-first-breeding, recruitment of first-generation offspring,

224 recruitment of successful first-generation offspring, lifespan, total number of mates, total number

225 of breeding attempts and breeding lifespan (see Supplementary Material S1).

226 The relationships between recruitment of first-generation breeders, successful first-generation

227 breeders, sex, and the effect of life-history traits (age-at-first-breeding, lifespan, total number of

228 mates, total number of breeding attempts, breeding lifespan) on LRS were analysed using a

229 generalised linear mixed models (GLMM) with a Poisson distribution and a random factor, mate

230 code, to account for pseudoreplication associated with mated pairs being included in the analysis,

231 using the lme4 package (Bates et al., 2015). Fit of the maximal model was assessed using

$232 R^{2} G L M M$ from the AICcmodavg package (Mazerolle 2016). We included only uncorrelated

233 variables within the same model $(r<0.6$; Hosmer \& Lemeshow 2005) to avoid multi-

234 collinearity. We used an information-theoretic approach to model selection, by constructing a

235 maximal model containing all probable input variables (based on a priori reasoning), and then

236 ranking this model against all of its derivatives using QAICc. To account for model selection 




238 Material S3), using the MuMIn and AICcmodavg packages in R (Bartoń, 2016; Mazerolle, 2016).

239 In order to compare specifically the life-history characteristics (age-at-first-breeding,

240 lifespan, total number of mates, total number of breeding attempts, breeding lifespan) between

241 birds which proved over the two generations to be highly successful breeders ("high quality"),

242 and the remainder of the birds (“ordinary"), we defined the highly successful individuals as

243 follows: those birds with above-average LRS relative to their sex (females $\geq 7$, males $\geq 6$ ) and

244 those that had an above-average number of grand-offspring (second-generation chicks; females $\geq$

24510 , males $\geq 6$ ). Using the same GLMM approach, we analysed the effect of life-history

246 parameters on the LRS of these two groups of birds to determine differences in breeder quality.

\section{RESULTS}

249 Of the total sample of 2147 birds marked as chicks or juveniles from 1981 to 2003,1546

$250(72.0 \%)$ were thought to have died before reaching adulthood, whereas 441 birds survived to be

251 seen at least once as an adult: 71 of these birds were sighted away from Boulder Beach at other

252 monitoring locations where they subsequently bred. Of the 370 birds that were re-sighted at

253 Boulder Beach as an adult at least once (17.2\%), 264 attempted to breed at least once (12.3\%),

254 and 219 bred successfully at least once (10.2\%). Only 124 birds produced at least one first-

255 generation chick that recruited to the breeding population and attempted to breed at least once

$256(5.8 \%)$, and 102 had first-generation offspring that not only recruited but bred successfully at

257 least once (4.8\%). Overall figures are presented in Table 1.

258 LRS of male and female yellow-eyed penguins 
259 There was high individual variance in LRS calculated for both males and females $(\mathrm{n}=130)$, with

260 this variance being higher for females (Table 2; Figure 2). The maximum number of total

261 offspring a female yellow-eyed penguin produced was 24 , compared to 23 for males. The only

262 significant differences between males and females were for recruitment of breeders $(\mathrm{W}=2554$,

$263 \mathrm{p}$-value $=0.03212)$ and recruitment of successful breeders $(\mathrm{W}=2615, \mathrm{p}$-value $=0.01198)$. There

264 was no difference between males and females for LRS $(\mathrm{W}=2452$, $\mathrm{p}$-value $=0.1077)$, age-at-

265 first-breeding $(\mathrm{W}=1750.5, \mathrm{p}$-value $=0.0791)$, lifespan $(\mathrm{W}=2169.5$, $\mathrm{p}$-value $=0.7755)$, total

266 number of mates, $(\mathrm{W}=2187.5, \mathrm{p}$-value $=0.6948)$, total number of breeding attempts $(\mathrm{W}=2370$,

267 -value $=0.2197)$, and breeding lifespan $(\mathrm{W}=2359.5, \mathrm{p}$-value $=0.2392)$.

\section{Relationships between fledging and recruitment}

269 There was a strong positive relationship between number of chicks fledged per parent (LRS) and 270 number that recruited for females $\left(\lambda\left(\right.\right.$ Female $\left._{i}\right)=\exp (-0.27) * \exp \left(0.12 * \mathrm{LRS}_{i}\right)$ and males

$271\left(\lambda\left(\right.\right.$ Male $\left._{i}\right)=\exp (-0.60) * \exp (0.13 *$ LRS $)$. There was also a significant positive relationship

272 between the number of chicks fledged (LRS) and number of successful recruits (i.e. recruits that

273 in turn successfully fledged offspring during at least one breeding attempt) for females

$274\left(\lambda\left(\right.\right.$ Female $\left.\left._{i}\right)=\exp (-0.65) * \exp \left(0.12 * \mathrm{LRS}_{i}\right)\right)$ and males $\left(\lambda\left(\right.\right.$ Male $\left._{i}\right)=\exp (-1.26) *$

$275 \exp (0.14 *$ LRS $)$.

\section{Life-history traits}

277 Lifespan was the strongest positive correlate of LRS $(0.61 \pm 0.03)$, followed by a negative

278 correlation with age-at-first-breeding $\left(-0.14 \pm 0.04\right.$; GLMM R ${ }^{2} \mathrm{~m}=0.56, \mathrm{R}^{2} \mathrm{c}=0.79$; Table 3).

279 There was a trend associated with sex, with males having slightly lower LRS compared to

280 females (Fig. 3). There was no association with the number of mates and LRS; or interactions

281 between sex, age-at-first-breeding or lifespan (Table 3). 


\section{Determining the traits of "high quality" breeders}

283 "High-quality" birds (i.e., those with above-average LRS and higher than average numbers of 284 successful breeding offspring; females $=16$, males $=16$ ) produced 389 fledged chicks, of which

285133 first-generation offspring recruited, and 94 were successful, producing 713 grand-offspring

286 (second-generation chicks) (Fig. 4). These higher-quality breeding birds produced 26 first-

287 generation offspring with an above-average LRS $\geq 6$. In contrast, the remaining "ordinary" birds 288 (females $=46$, males $=52$ ) produced 379 chicks, of which 100 first-generation offspring 289 recruited, and 55 were successful in producing 252 grand-offspring (second-generation chicks)

290 (Fig. 4). The ordinary breeding birds $(\mathrm{n}=98)$ produced 10 above-average first-generation 291 offspring.

An interaction effect between breeder type and lifespan was detected, but there was no 293 interaction between age-at-first breeding and breeder type (Table 4), despite the ordinary female 294 birds beginning breeding at least one year younger than the high-quality female birds (Table 5).

295 The ordinary birds had shorter lifespans and therefore lower LRS, with high-quality birds having 296 on average double the longevity of their short-lived conspecifics (Table 5).

\section{DISCUSSION}

299 By tracking reproductive success in yellow-eyed penguins over more than one generation we 300 show that only a small proportion of fledglings survive, recruit, and attempt to breed, however 301 lifetime reproductive success and survival appears to be an inter-generational trait, with above302 average breeders more likely to produce chicks that will be highly successful breeders. Fewer 303 than $1.5 \%$ (32 of 2147) of these breeding birds are what we call "super-breeders". These "super- 
304 breeders" appear to be successful in producing offspring that will themselves survive and go on 305 to contribute disproportionately to the next generation.

Only $10.2 \%$ of the sample population of 2147 fledgling yellow-eyed penguins eventually

307 308

recruited and produced offspring at all, meaning that $89.8 \%$ of young fledged did not contribute to the next generation at Boulder Beach. Low juvenile survival is likely to be the principal reason for the low number of penguins recruiting to breeding populations. Only $20.5 \%$ of yellow-eyed penguin fledglings survived to sexual maturity (two years of age, including birds that did not recruit), a similar proportion to the $20.8 \%$ yellow-eyed penguins resighted as sexually-mature adults at the Boulder Beach complex between 1981 to 1990 (Efford, Darby \& Spencer, 1996), although our reported result includes $3.3 \%$ of birds that were resighted away from Boulder Beach. Our survival to adulthood rate was higher than the 10.4\% of Adélie penguins (Pygoscelis adeliae) that survived to age two (Ainley \& DeMaster, 1980), but low compared to the range of values for survivorship from fledging to sexual maturity for 19 species of passerines and seabirds (42 - 86\%; Newton, 1989). Survivorship to two years was significantly lower than reported in several other studies of seabirds, including 57.6\% for common guillemots (Uria aalge; Crespin et al., 2006), 41 to 54\% for sooty shearwaters (Puffinus griseus; Fletcher et al., 2013), and $c$. 77\% for king penguins after one year (Aptenodytes patagonicus; Saraux et al., 2011). It was even lower than the c. 32\% of yellow-eyed penguins that survived to age two between 1936 and 1952 (Richdale, 1957).

The probability that birds survive the period between parental care and adulthood has a large influence on population dynamics, but is highly variable (Maness \& Anderson, 2013). The most common hypothesis for high rates of mortality in young birds is their lack of experience, poor foraging skills and physical immaturity (Lack, 1954; Ashmole, 1963; Orians, 1969; Dunn, 
327 1972). Positive correlations are predicted between body mass and juvenile survival, based on the

328 assumption that heavier juveniles have fat reserves that buffer the food limitation associated with

329 inexperience (Lack, 1966; McClung et al., 2004; Maness \& Anderson 2013). Yellow-eyed

330 penguins are sedentary foragers that lack a long-distance migratory phase in their life history,

331 however juveniles undergo a pelagic phase lasting for up to two years, during which time they

332 are sighted only erratically along the coast. No information exists on where juveniles disperse to

333 (Darby \& Seddon, 1990), and most mortality occurs during this post-fledging pelagic phase. It is

334 unclear whether the low survival of juvenile penguins in this study is normal or depressed by

335 changing environmental conditions.

This study indicates that of the chicks seen again at Boulder Beach after fledging $(24.7 \%$

337 of the original sample), $69.8 \%$ were seen at two years of age (i.e. up to the onset of sexual

338 maturity, $69.8 \%$, Table 1), but only $49.8 \%$ survived to breed at least once. These figures suggest

339 that juvenile mortality occurs in two or more stages: as high post-fledging mortality due to

340 inexperience, immaturity and lack of skill, and possibly due to seasonal fluctuations in prey

341 availability later in the breeding season when juveniles must prepare for their first annual moult.

342 The difference in juvenile survival between Richdale's (1957) study and ours may be indicative

343 of an adverse change in foraging conditions (Browne et al., 2011; Mattern et al., 2014),

344 entanglement in recreational or commercial fishing gear (Darby \& Dawson, 2000), increasing

345 frequency of poor seasons (van Heezik 1990), and competition with or predation by recovering

346 otariid populations (Bradshaw, Lalas \& Thompson, 2000; Lalas et al., 2007), all of which are

347 documented to affect adult yellow-eyed penguins. Marine pollution that results in disease

348 outbreaks and mass mortality events, have also been hypothesised (e.g. 1990 mass mortality 
349 event, Gill \& Darby 1993; e.g. diphtheritic stomatitis, Alley et al., 2004, 2017; Trathan et al., 350 2015).

From the sample of 2147 fledglings, the proportions that survived and attempted breeding

352 (12.3\%), fledged offspring (10.2\%) and fledged offspring that recruited (5.8\%) seem low.

353 However, the proportion of birds that attempted breeding and were successful is relatively high

354 (219 of $264,82.9 \%)$. In other words, if a bird was successful in surviving to make a breeding 355 attempt, there was an $83 \%$ probability that it would be successful in fledging at least one chick in 356 its lifetime, a 47\% (124/264) probability it would fledge at least one chick that would recruit to 357 the breeding population, and a 39\% (102/264) probability that the bird would fledge chicks that 358 would recruit and subsequently fledge offspring. The proportion of yellow-eyed penguins 359 surviving to attempt to breed at least once was comparatively lower than in red-billed gulls 360 (Larus novaehollandiae, 18 - 22\%), little penguins (Eudyptula minor, 28 -35\%), kittiwakes 361 (Rissa tridactyla, $34-42 \%$ ) and short-tailed shearwaters (P. tenuirostris, 69 - 73\%). However 362 the proportion of breeding yellow-eyed penguins that produced recruits $(47 \%)$ is one of the 363 highest, with only kittiwakes having similar recruitment rates (c. 41 - 50\%) (Coulson, 1988; 364 Wooller et al., 1988; Mills, 1989; Dann \& Cullen, 1990; Moreno, 2003). In yellow-eyed 365 penguins, recruitment into the breeding population appears to be driven in part by the higher 366 survival rate of the offspring of a subset of breeders, with high-quality birds, labelled here as 367 “super-breeders", producing more recruits (133 first-generation recruits from 32 birds, 57.1\%) 368 than the ordinary breeders (100 first-generation recruits from 98 birds, 42.9\%). Both male and female penguins that survived to breed varied considerably in the total number of offspring they fledged. For a long-lived species, the average number of fledged young

371 seems relatively small (female mean $=6.82$, male mean $=5.07)$, but falls within the range of 
372 values reported from the few studies that have estimated mean LRS in seabirds, passerines and

373 birds of prey, demonstrating that LRS for many species of birds remain similar as a result of life-

374 history trade-offs (Table 6). Females had slightly longer lifespans and longer breeding lifespans

375 than males, because females started breeding earlier than males. Females may have more

376 opportunities to breed than males, due to an apparent sex-skew, with males outnumbering

377 females (Richdale, 1957). The maximum number of fledged offspring for both male (23) and

378 female yellow-eyed penguins (24) was much higher than mean values, reflecting the highly

379 negatively skewed distribution of LRS (Fig.2). This is consistent with the observation that most

380 individuals produce small numbers of young, and only a few produce many (Newton 1989).

381 Nevertheless, there was a wide range in the number of young fledged by individual birds

382 regardless of sex, despite the greater cost of reproduction incurred by breeding females. Newton

383 (1989) concluded that LRS is generally similar for males and females in species that lack high

384 levels of sexual dimorphism, which is the case for yellow-eyed penguins (Seddon et al., 2013).

\section{LRS predictors}

386 Lifespan was the strongest correlate of LRS, with the number of offspring produced increasing

387 significantly with increased lifespan. This trend is very common for seabirds (Clutton-Brock,

388 1988; Newton, 1989; Newton, 1995), and is attributed to a number of factors: increased breeding

389 opportunities, and increasing parental experience with lifespan, as has been demonstrated in

390 other seabird species (Limmer \& Becker, 2009; Saraux et al., 2012), and the general fitness

391 required for a long lifespan. Long-lived birds are the primary contributors to the gene pool in

392 many species, meaning there is likely to be selection for viability (Moreno, 2003; Mauck,

393 Huntington \& Grubb, 2004). We found that high-quality breeders had lifespans that were on

394 average double that of ordinary breeders, but they produced three to four times more offspring in 
395 their lifetimes than ordinary birds (Table 5). In other species lifespan explains less of the

396 variance when the number of recruits is examined, as opposed to number of offspring produced

397 (Newton, 1989). In contrast, we found a highly significant relationship between LRS and the

398 number of recruits and successful recruits produced for yellow-eyed penguins, meaning that the

399 characteristics of birds with longer lifespans are likely to be reliable predictors of parental quality

400 for this species.

401 Age-at-first-breeding was the second strongest predictor of LRS in yellow-eyed

402 penguins, with birds that began breeding later having lower lifetime totals of offspring, due to a 403 decrease in total breeding opportunities (Newton, 1989). The theory of antagonistic pleiotropy 404 suggests that high early-life reproductive output is at the expense of later-life productivity, and 405 can be selected for if selection is stronger at early stages of life, so that early benefits outweigh 406 later costs (Williams, 1957). While there was a difference between the LRS of males and 407 females in this study, no interaction effect could be detected, despite earlier reproduction in 408 females, which may potentially result in accelerated reproductive senescence (Partridge, 1992,

409 Reed et al., 2008). This trend has been observed in several long-lived bird species, which all 410 showed a positive correlation between age-at-first-breeding and survival in females, suggesting a 411 trade-off between early recruitment and lifespan (Ollason \& Dunnet,1978; Ainley \& DeMaster, 412 1980; Pyle et al., 1997; Tavecchia et al., 2001). Individual variation in LRS for yellow-eyed 413 penguins therefore appears to be due to variation in lifespan (1-24 years) and age-at-first414 breeding (2-12 years), together determining the length of the breeding lifespan (1-18 years).

415 It is common for many species of seabirds to show reduced breeding success after 416 changing mates, most likely due to a trade-off in time and energy expenditure for finding a new 417 mate and foraging, and also due to lack of familiarity with the new mate (Ollason \& Dunnet, 
418 1978; Coulson \& Thomas, 1985; Newton, 1989). In short-tailed shearwaters a mate change

419 results in a temporary decrease in breeding success, but this effect is smaller in individuals that

420 are more experienced breeders (Wooller et al., 1989). Breeding success of male common

421 guillemots decreased with an increasing number of mates (Lewis et al. 2006). Yellow-eyed

422 penguins that change mates are more likely to experience breeding failure the subsequent year

423 (Setiawan et al., 2005). We did not detect a significant negative effect of number of mates on

424 lifetime number of offspring produced, possibly due to the tendency for longer-lived birds to

425 outlive their mates, resulting in higher overall numbers of mates.

\section{Conservation implications}

427 Chronic and acute stress as a result of climate change, marine pollution, disturbance at terrestrial

428 breeding sites and extreme nutritional stress may decrease LRS, as the cumulative effects of

429 increasing types of stressors force individuals to reduce their investment in productivity, increase

430 breeding skip behaviours (e.g. red-footed boobies Sula sula, Cubayanes et al., 2011) or result in

431 breeder mortality (Kitaysky et al., 2010). In black-legged kittiwakes, breeding behaviour is

432 mediated by increased corticosterone production during periods of poor food supply (Kitaysky et

433 al., 2010; Schultner et al. 2013). Clarifying the factors that separate the success of the few that

434 produce many offspring from the many that do not may therefore need to take into account the

435 role of chronic or acute stress on the parameters that may be used to measure their fitness.

436 Likewise, birds that contribute disproportionately to successive generations may have higher

437 thresholds for anthropogenic and environmental stressors than average birds. The impact of

438 extreme events on different phenotypes of conspecifics may differ as a consequence of the

439 "super-breeder" phenomenon, since these birds tend to consistently achieve high LRS and long-

440 lifespans in a stochastic environment. 
It appears that the Boulder Beach population of yellow-eyed penguins is sustained by a

442 small proportion of high-quality, long-lived birds, the "super-breeders". High levels of philopatry

443 may drive high-quality and ordinary breeding recruits to return to their natal area, and once they

444 begin breeding they are likely to remain at these breeding sites for life. This behaviour may be

445 hazardous for population stability should either one of their marine or terrestrial habitats become

446 threatened. If circumstances require it necessary to protect specific individuals in a population

447 from catastrophe, or to differentially allocate resources due to budget constraints, it would be

448 important to distinguish between potentially very successful breeders and the evolutionary

449 "living dead" (Moreno, 2003). Oiling is the greatest anthropogenic threat to penguins (Trathan et

450 al., 2015), requiring triage of breeders for temporary captive management. The unexplained mass

451 mortalities of adult and juvenile yellow-eyed penguins on the Otago Peninsula in 1990, 1996 and

4522013 due to exposure to an unknown toxic agent have presented conservation managers with

453 opportunities to safeguard specific individuals from harm (Gill \& Darby, 1993; DOC,

454 unpublished data). While effort should be placed on safeguarding all individuals in a threatened

455 population during a period of catastrophe, only a small proportion of individuals will contribute

456 to the recovery of the population following such an event.

Although it seems sensible to focus conservation resources on "super-breeders", the

458 challenge lies in identifying them. The positive relationship between LRS and the number of

459 successful recruits indicates that birds demonstrating relatively high LRS are also those that

460 produce high-quality offspring. Lifespan is the main predictor of LRS, but unfortunately it

461 cannot be calculated until the death of an individual. Age-at-first-breeding can be identified

462 before death, although its association with potential LRS is much weaker, however high-quality

463 female birds tended to recruit a year later than ordinary birds. Fledging weight of the individual 
464 could indicate that the individual comes from a high quality lineage and will be more likely to

465 survive (McClung et al. 2004) and go on to breed and produce high quality offspring that also

466 fledge at a higher than average weight. We could not explore this relationship with our dataset as

467 fledging weights were not reliably recorded for historical records. The value of other potential

468 indicators of living super-breeders include oxidative stress, white blood cell counts, hue and size

469 of the coloured eye and eye stripe; these are being explored in ongoing research.

It may be possible to single out birds on the basis of life-history traits that relate to state-

471 based quality. The importance of state-based assessments for yellow-eyed penguins has yet to be

472 fully explored, especially with regard to analysing the immunocompetence of individuals.

473 Disease prevalence has increased in recent years (Alley et al., 2004, 2017; Hill et al., 2010;

474 Argilla et al., 2013). Moreno et al. (1998) measured variables related to health state and cell-

475 mediated immunity between early and late breeders for chinstrap penguins ( $P$. antarctica),

476 finding that early breeders experienced better health than later breeders. Female chinstrap

477 penguins with leukocytosis laid smaller eggs, had slower chick growth rates, and were more

478 prone to failure (Moreno et al., 1998). Information about foraging ecology, particularly in young

479 birds is also necessary. Foraging strategies in high quality Adélie penguins have been linked to

480 better provisioning of chicks, suggesting that some birds may be physiologically more capable

481 by virtue of genetic superiority (Lescroël et al., 2010).

482

Around half of all seabird species globally are thought to be in decline, many of which

483

have restricted numbers and ranges, and demographic characteristics that severely limit their rate

484 of recovery (Croxall et al. 2012). As long-lived species, and with demographic characteristics

485 similar to those of yellow-eyed penguins, it is likely that population persistence in other species

486 is also dependent to some extent on a subset of successful breeders. Understanding what causes 
487 some birds to display enhanced resilience and identifying and protecting these individuals may

488 be vital in the face of growing threats.

489

490

\section{ACKNOWLEDGEMENTS}

491 This study would not have been possible without the following individuals who contributed their 492 data: Kerri-Anne Edge, Ursula Ellenberg, Mike Hazel, Melanie Massaro, Thomas Mattern, Dean

493 Nelson, and Alvin Setiawan. Thanks also to Bruce McKinlay and Dave Houston (DOC) for 494 access to the Yellow-eyed Penguin Database, and David Ainley and two anonymous reviewers 495 whose constructive comments greatly improved the manuscript.

496

\section{REFERENCES}

498

499

500

501

502

503

504

505

506

507

508

509

510

Ainley DG, DeMaster DP. 1980. Survival and mortality in a population of Adélie penguins. Ecology 61: 522-530.

Alley MR, Morgan KJ, Gill JM, Hocken AG. 2004. Diseases and causes of mortality in yelloweyed penguins, Megadyptes antipodes. Kokako 11(2): 18-23.

Alley MR, Suepaul RB, McKinlay B, Young MJ, Wang J, Morgan KJ, Hunter SA, and Gartrell BD, 2017. Diphtheritic stomatitis in yellow-eyed penguins (Megadyptes antipodes) in New Zealand. Journal of Wildlife Diseases 53 (1): DOI: 10.7589/2015-07-195

Argilla LS, Howe L, Gartrell BD, Alley MR. 2013. High prevalence of Leucocytozoon spp. in the endangered yellow-eyed penguin (Megadyptes antipodes) in the sub-Antarctic regions of New Zealand. Parasitology 140(5): 672-682.

Ashmole N P. 1963. The regulation of numbers of tropical oceanic birds. Ibis 103(3): 458-473.

Bartoń K. 2016. MuMIn: Multi-Model Inference. R package version 1.15.6. https:/CRAN.Rproject.org/package=MuMIn. 
511 Bates D, Maechler M, Bolker B, Walker S. 2015. Fitting Linear Mixed-Effects Models Using 512 lme4. Journal of Statistical Software 67(1), 1-48. doi:10.18637/jss.v067.i01.

513 BirdLife International, 2015. Species factsheet: Megadyptes antipodes. Downloaded from 514 http://www.birdlife.org on 14/08/2015.

515 Boersma PD. 1978. Breeding patterns of Galapagos penguins as an indicator of oceanographic conditions. Science 200:1481-1483.

517 Bradley J, Wooller R, Skira I, Serventy D. 1990. The influence of mate retention and divorce 518 upon reproductive success in Short-tailed Shearwaters Puffinus tenuirostris. Journal of Animal Ecology 58: 487-496.

521

522

Bradshaw CJA, Lalas C, Thompson CM. 2000. Clustering of colonies in an expanding 105-112.

523 Brommer JE, Pietiäinen H, Kolunen H. 1998. The effect of age at first breeding on Ural Owl 524 lifetime reproductive success and fitness under cyclic food conditions. Journal of Animal $525 \quad$ Ecology 67: 359-369.

526 Brommer J E, Ahola K, Karstinen T. 2005. The colour of fitness: plumage coloration and 527 lifetime reproductive success in the tawny owl. Proceedings of the Royal Society of London

529

530

531

532 533

534 535

536 537 Breeding Systems. Chicago: University of Chicago Press. 548p. B 272: 935-940.

Browne T, Lalas C, Mattern T, van Heezik Y. 2011. Chick starvation in yellow-eyed penguins: Evidence for poor diet quality and selective provisioning of chicks from conventional diet analysis and stable isotopes. Austral Ecology 36: 99-108.

Bryant D. 1979. Reproductive costs in the House Martin Delichon urbica. Journal of Animal Ecology 48: 655-675.

Chastel O, Weimerskirch H, Jouventin P. 1995. Influence of body condition on reproductive decision and reproductive success in the Blue Petrel. The Auk 112: 964-972.

Clutton-Brock TH. 1988. Reproductive success: Studies of Individual Variation in Contrasting 
538 Costantini D, Meillère A, Carravieri A, Lecomte V, Sorci G, Faivre B, Weimerskirch H,

539 Bustamante P, Labadie P, Budzinski H, Chastel O. 2014. Oxidative stress in relation to

540 reproduction, contaminants, gender and age in a long-lived seabird. Oecologia 175: 1107-

$541 \quad 1116$.

542 Coulson Thomas C. 1985. Differences in the breeding performance of individual kittiwake gulls, 543 Rissa tridactyla. In: R.M. Sibley and Smith, R.H. (eds.). Behavioural Ecology: p. 489-503. 544 Blackwell Scientific Publications, London.

545 Coulson J C. 1988. Lifetime reproductive success in the Black-legged Kittiwake (Rissa 546 tridactyla). In: Ouellet H, ed. Acta XIX Conguessus Internationalis Ornithologici Vol. 2., p. 547 2140-2147. Ottawa: University of Ottawa Press.

548 Crawford RJM, Davis SA, Harding RT, Jackson LF, Leshoro TM, Meÿer M., Randall RM, 549 Underhill LG, Upfold L, van Dalsen AP, van der Merwe E, Whittington PA, Williams AJ, 550 Wolfhaardt AC. 2000. Initial impact of the Treasure oil spill on seabirds off western South 551

552 Crespin L, Harris MP, Lebreton JD, Frederiksen M, Wanless S. 2006. Recruitment to a seabird 553 population depends on environmental factors and on population size. Journal of Animal Ecology 75:228-238.

555 Croxall JP, Butchart, SHM, Lascelles B, Stattersfield AJ, Sullivan B, Symes A, Taylor P. 2012.

556 Seabird conservation status, threats and priority actions: a global assessment. Bird

557 Conservation International 22(1): 1-34. Doi: https://doi.org/10.1017/s0959270912000020

558 Cubayanes S, Doherty PF, Schieber EA, and Gimenez O. 2011. To breed or not to breed: a 559 seabird's response to extreme climatic events. Biology Letters 7: 303-306.

560 Dann P, Cullen J. 1990. Survival, patterns of reproduction, and lifetime reproductive output in 561 Little Blue Penguins Eudyptula minor on Phillip Island, Victoria, Australia. In: Davis LS, 562 Darby JT, eds. Penguin Biology. p. 63-84. San Diego: Academic Press.

563 Darby JT, Dawson SM. 2000. Bycatch of yellow-eyed penguins (Megadyptes antipodes) in 564 gillnets in New Zealand waters 1979 - 1997. Biological Conservation 93: 327 - 332. 
565 Darby JT, Seddon PJ. 1990. Breeding biology of Yellow-eyed Penguins Megadyptes antipodes. 566 In: Davis LS, Darby JT, eds. Penguin Biology: 45-62. San Diego: Academic Press.

567 Daunt F, Wanless S, Harris MP, Money L, Monaghan P. 2007. Older and wiser: improvements 568 in breeding success are linked to better foraging performance in European shags. Functional 569 Ecology 21: $561-567$.

570 Dunn EK. 1972. The effect of age on the fishing ability of sandwich terns, (Sterna sandvicensis).

571

572

573

574

575

576

577

578

579

580

581

582

583

584

585

586

587

588

589

590

591

592

593 Ibis 114: 360-366.

Efford M, Darby J, Spencer N. 1996. Population studies of Yellow-eyed Penguins. Science for Conservation 22. Department of Conservation, Wellington. 29p.

Ellenberg U, Setiawan AN, Cree A, Houston DM, Seddon PJ. 2007. Elevated hormonal stress response and reduced reproductive output in yellow-eyed penguins exposed to unregulated tourism. General and Comparative Endocrinology 152: 54-63.

Ens BJ, Kersten M, Brenninkmeijer A, Hulscher JB. 1992. Territory quality, parental effort and reproductive success of oystercatchers Haematopus ostralegus. Journal of Animal Ecology 61: 703-715.

Fletcher D, Moller H, Clucas R, Bragg C, Scott D, Scofield P, Hunter CM, Win I W, Newman J, McKechnie S, De Cruz J, Lyver P. 2013. Age at First Return to the Breeding Colony and Juvenile Survival of Sooty Shearwaters. Condor 115: 465-476.

Forslund P, Pärt T. 1995. Age and reproduction in birds - hypotheses and tests. Trends in Ecology and Evolution 10(9): 375-378.

Fowler GS. 1995. Stages of age-related reproductive success in birds: simultaneous effects of age, pair-bind duration and reproductive experience. American Zoology 35: 318-328.

Froy H, Phillips RA, Wood AG, Nussey DH, Lewis S. 2013. Age-related variation in reproductive traits in the wandering albatross: evidence for terminal improvement following senescence. Ecology Letters 16: 642-649.

Garamszegi LZ, Török J, Michl G, Møller AP. 2004. Female survival, lifetime reproductive success and mating status in a passerine bird. Oecologia 138: 48-56.

Gartrell BD, Collen R, Dowding JE, Gummer H, Hunter S, King EJ, Laurenson L, Lilley CD, Morgan KJ, McConnell HM, Simpson K, Ward JM. 2013. Captive husbandry and veterinary 
594 care of northern New Zealand dotterels (Charadrius obscurus aquilonius) during the CV 595 Rena oil-spill response. Wildlife Research 40: 624-632.

596 Gavin TA, Bollinger EK. 1988. Reproductive correlates of breeding-site fidelity in Bobolinks 597 Dolichonyx oryzivorus. Ecology 69: 96-103.

598 Gill JM, Darby JT. 1993. Deaths in yellow-eyed penguins (Megadyptes antipodes) on the Otago 599 Peninsula during the summer of 1990. New Zealand Veterinary Journal 41: 39-42.

600 Goldsworthy SD, Gales RP, Giese M, Brothers N. 2000. Effects of the Iron Baron oil spill on 601 602 603 604 605 606 little penguins (Eudyptula minor). I. Estimates of mortality. Wildlife Research 27: 559-571.

Gustafsson L. 1986. Lifetime reproductive success and heritability: empirical support for Fisher's fundamental theorem. The American Naturalist, 128: 761-764.

Hegg D, Giroir T, Ellenberg U, Seddon PJ. 2012. Yellow-eyed penguin (Megadyptes antipodes) as a case study to assess the reliability of nest counts. Journal of Ornithology 153(2): 457466.

Hill A, Howe L, Gartrell B, Alley M. 2010. Prevalence of Leucocytozoon spp., in the endangered Yellow-eyed Penguin Megadyptes antipodes. Parasitology 137: 1477-1485.

Hosmer DW, Lemeshow S. 2005. Introduction to the Logistic Regression Model. Applied Logistic Regression (John Wiley \& Sons, Inc.), pp 1-30.

Jensen H, Sæther BE, Ringsby TH, Tufto J, Griffith SC, Ellegren H. 2004. Lifetime reproductive 614 Kim S.-Y, Velando A, Torres R, Drummond H. 2011. Effects of recruiting age on senescence, 615 lifespan and lifetime reproductive success in a long-lived seabird. Oecologia 166: 615-626.

616 King SD, Harper GA, Wright JB, McInnes JC, van der Lubbe JE, Dobbins M, Murray SJ. 2012. 617 Site-specific reproductive failure and decline of a population of the endangered yellow-eyed 618 penguin: a case for foraging habitat quality. Marine Ecology Progress Series 467: 233-244.

619 Kitaysky AS, Piatt JF, Hatch SA, Kitaiskaia EV, Benowitz-Frdericks ZM, Shultz MT, Wingfield 620 JC. 2010. Food availability and population processes: severity of nutritional stress during reproduction predicts survival of long-lived seabirds. Functional Ecology 24: 625-637. 
622 Korpimäki E. 1992. Fluctuating food abundance determines the lifetime reproductive success of 623 male Tengmalm's Owls. Journal of Animal Ecology 61: 103-111.

624 Krüger O, Lindström J. 2001. Lifetime reproductive success in Common Buzzard, Buteo buteo: 625 from individual variation to population demography. Oikos 93: 260-273.

626 Lack DL. 1954. The Natural Regulation of Animal Numbers. Oxford: Clarendon Press, 343p.

627 Lack D L. 1966. Population studies of birds. Oxford: Clarendon Press. 341p.

628 Lalas C, Ratz H, McEwan K, McConkey SD. 2007. Predation by New Zealand sea lions 629 (Phocarctos hookeri) as a threat to the viability of yellow-eyed penguins (Megadyptes antipodes) at Otago Peninsula, New Zealand. Biological Conservation 135: 235-246.

Lescroël A, Ballard G, Toniolo V, Barton KJ, Wilson PR, Lyver PO'B, Ainley DG. 2010.

632 Working less to gain more: when breeding quality relates to foraging efficiency. Ecology 91(7): 2044-2055.

635

Lewis S, Wanless S, Elston DA, Schultz MD, Mackley E, Du Toit M, Underhill JG, Harris MP. 2006. Determinants of quality in a long-lived colonial species. Journal of Animal Ecology 75: 1304-1312.

Limmer B, Becker PH. 2009. Improvement in chick provisioning with parental experience in a seabird. Animal Behaviour 77: 1095-1101.

Maness TJ, Anderson DJ. 2013. Predictors of juvenile survival in birds. Ornithological Monographs 78: 1-55.

Massaro M, Darby JT, Davis LS, Edge K-A, Hazel MJ. 2002. Investigation of interacting effects 642 of female age, laying dates, and egg size in yellow-eyed penguins (Megadyptes antipodes). The Auk 119(4): 1137-1141.

Massaro M, Davis LS, Darby JT. 2003. Carotenoid-derived ornaments reflect parental quality in male and female yellow-eyed penguins (Megadyptes antipodes). Behavioural Ecology and Sociobiology 55: 169-175.

648

Massaro M, Davis LS, Darby JT, Robertson GJ, Setiawan AN. 2004. Intraspecific variation of 649 incubation periods in yellow-eyed penguins Megadyptes antipodes: testing the influence of age, laying date and egg size. Ibis 146: 526-530. 
650 Mattern T, Ellenberg U, Houston DM, Davis LS. 2007. Consistent foraging routes and benthic 651 foraging behaviour in Yellow-eyed Penguins. Marine Ecology Progress Series 343: 295652306.

653 Mattern T, Ellenberg U, Houston DM, Lamare M, Davis LS, van Heezik Y, Seddon PJ. 2014.

654 Straight line foraging in yellow-eyed penguins: new insights into cascading fisheries effects

655

656 and orientation capabilities of marine predators. PLOS ONE 8(12): e84381.

657 doi:10.1371/journal.pone.0084381

658

Mauck RA, Huntington CE, Grubb TC. 2004. Age-specific reproductive success: evidence for 659 the selection hypothesis. Evolution 58(4): 880-885.

Mazerolle MJ, 2016. AICcmodavg: Model selection and multimodel inference based on

660

661 (Q)AIC(c). R package version 2.0-4. http://CRAN.R-project.org/package=AICcmodavg.

McClung MR, Seddon PJ, Massaro M, Setiawan A. 2004. Nature-based tourism impacts on 663 664 665

McKinlay B. 2001. Hoiho Megadyptes antipodes recovery plan, 2000-2025. Threatened Species Yellow-eyed Penguins Megadyptes antipodes: does unregulated visitor access affect

666 Recovery Plan 35. Department of Conservation, Wellington. 27p.

667

Mills JA. 1989. Red-billed Gull. In: Newton I, ed. Lifetime Reproduction in Birds: p. 387-404. London: Academic Press.

Moore PJ. 1994. What is a Bad Season for Yellow-eyed Penguins? Conservation Advisory Science Notes No. 103. Department of Conservation, Wellington. 7p.

Moore PJ. 1999. Foraging range of the Yellow-eyed Penguin Megadyptes antipodes. Marine Ornithology 27: 49-58.

Moreno J, De Leon A, Fargallo JA, Moreno E. 1998. Breeding time, health and immune response in the chinstrap penguin (Pygoscelis antarcticus). Oecologia 115: 312-319. implications for conservation. Scientia Marina 67: 7-12. 
676 Newton I. 1988. Age and reproduction in the Sparrowhawk. In: Clutton Brock, T.H. (ed.)

677 Reproductive Success: Studies of Individual Variation in Contrasting Breeding Systems, p.

678 201-219. Chicago: University of Chicago Press.

679 Newton I. 1989. Lifetime reproduction in birds. Academic Press, London. 479p.

680 Newton I. 1995. The contribution of some recent research on birds to ecological understanding.

681 Journal of Animal Ecology 64: 675-695.

682 Nisbet ICT, Dann P. 2009. Reproductive performance of little penguins Eudyptula minor in 683 relation to year, age, pair-bond duration, breeding date and individual quality. Journal of 684 Avian Biology 40: 296-308.

685

686

687

Orians GH. 1969. On the evolution of mating systems in birds and mammals. American 688 Naturalist 103: 589-603.

Partridge L. 1992. Measuring reproductive costs. Trends in Ecology and Evolution 7(3): 99-100.

Petersen SL, Branch GM, Ainley DG, Boersma PD, Cooper J, Woehler EJ. 2005. Is flipper banding of penguins a problem? Marine Ornithology,33: 75-79.

692

693

694

Potti J, Canal D, Serrano D. 2013. Lifetime fitness and age-related female ornament signalling: evidence for survival and fecundity selection in the pied flycatcher. Journal of Evolutionary Biology 26: 1445-1457.

Pyle P, Nur N, Sydeman WJ, Emslie SD. 1997. Cost of reproduction and the evolution of deferred breeding in the Western Gull. Behavioural Ecology 8: 140-147.

R Core Team, 2016. R: A language and environment for statistical computing. R Foundation for Statistical Computing, Vienna, Austria. URL https://www.R-project.org/. penguins (Megadyptes antipodes), at two locations on Otago Peninsula, South Island, New Zealand, 1991-96. New Zealand Journal of Zoology 31: 133-147. 
702 Reed TE, Kruuk LE, Wanless S, Frederiksen M, Cunningham EJ, Harris MP. 2008.

703 Reproductive senescence in a long-lived seabird: rates of decline in late-life performance are $704 \quad$ associated with varying costs of early reproduction. American Naturalist 171: E89-E101.

705 Richdale LE. 1957. A Population Study of Penguins. Oxford University Press, Oxford. 195p.

706 Ryder J. 1980. The influence of age on the breeding biology of colonial nesting seabirds.

707 Behavior of Marine Animals: Current Perspectives in Research 4: 153-168.

708 Saraux C, Le Bohec C, Durant JM, Viblanc VA, Gauthier-Clerc M, Deaune D, Park YH, Yoccoz 709 NG, Stenseth C, Le Maho Y. 2011. Reliability of flipper-banded penguins as indicators of $710 \quad$ climate change. Nature 469: 203-206.

711 Saraux C, Friess B, Le Maho Y, Le Bohec C. 2012. Chick-provisioning strategies used by king 712 penguins to adapt to a multiseasonal breeding cycle. Animal Behaviour 84: 675-683.

713 Schubert KA, Mennill DJ, Ramsay SM, Otter KA, Boag PT, Ratcliffe LM. 2007. Variation in 714 social rank acquisition influences lifetime reproductive success in Black-capped Chickadees. 715 Biological Journal of the Linnaean Society 90: 85-95.

716 Schultner J, Kitaysky AS, Gabrielsen GW, Hatch SA, Bech C. 2013. Differential reproductive 717 responses to stress reveal the role of life-history strategies within a species. Proc. R. Soc. B.

721 Seddon PJ, van Heezik Y, Ellenberg U. 2013. Yellow-eyed penguin. In: Borboroglu PG, 722 Boersma PD, eds. Penguins: Natural History and Conservation. Seattle: University of 723 Washington Press. 360p.

724 Setiawan AN, Darby JT, Lambert DM. 2004. The use of morphometrics to sex yellow-eyed 725 penguins. Waterbirds 27: 96-27.

726 Setiawan AN, Massaro M, Darby JT, Davis LS. 2005. Mate and territory retention in Yellow727 eyed Penguins. The Condor 107: 703-709.

728 Stokes DL, Boersma PD. 1998. Nest-site characteristics and reproductive success in Magellanic 729 Penguins (Spheniscus magellanicus). The Auk 115: 34-49. 
730 Stokes DL, Boersma PD. 2000. Nesting density and reproductive success in a colonial seabird, 731 the Magellanic Penguin. Ecology 81: 2878-2891.

732 Tavecchia G, Pradel R, Boy V, Johnson AR., Cézilly F. 2001. Sex-and age-related variation in 733 survival and cost of first reproduction in Greater Flamingos. Ecology 82: 165-174.

734 Trathan PN, García-Borboroglu P, Boersma PD, Bost CA, Crawford RJM, Crossin GT, Cuthbert 735

736

737

738

739

740 RJ, Dann P, Davis LS, de la Puente S, Ellenberg U, Lynch HJ, Mattern T, Pütz K, Seddon PJ, Trivelpiece W, Wienecke B. 2015. Pollution, habitat loss, fishing and climate change as critical threats to penguins. Conservation Biology 29(1): 31-41.

van Heezik Y. 1990. Seasonal, geographical, and age-related variations in the diet of the yelloweyed penguin (Megadyptes antipodes). New Zealand Journal of Zoology 17: 201-212.

van Heezik Y, Seddon PJ. 1989. Stomach sampling in the yellow-eyed penguin: Erosion of otoliths and squid beaks. Journal of Field Ornithology 60: 451-458.

742 Wauters L, Dhont AA. 1989. Body weight, longevity, and reproductive success in red squirrels

743 (Sciurus vulgaris). Journal of Animal Ecology 58: 637-651.

744 Wendeln H, Becker PH. 1999. Effects of parental quality and effort on the reproduction of 745 common terns. Journal of Animal Ecology 68: 205-214.

746

747

Williams GC. 1957. Pleiotropy, natural selection, and the evolution of senescence. Evolution 11:

748 Wooller R, Bradley J, Serventy D, Skira I. 1988. Factors contributing to reproductive success in 749 750 Short-tailed Shearwaters Puffinus tenuirostris. In: Proceedings of the International Ornithological Congress 19: 848-856.

751 Wooller RD, Bradley JS, Skira IJ, Serventy DL. 1989. Short-tailed Shearwater. In: Newton, I. 752 (ed.) Lifetime Reproduction in Birds. p. 405-417. London: Academic Press.

753 Wooller R, Bradley J, Skira I, Serventy D. 1990. Reproductive success of Short-tailed 754 Shearwaters Puffinus tenuirostris in relation to their age and breeding experience. Journal of 755 Animal Ecology 59: 161-170.

756 Wooller RD, Bradley JS, Croxall JP. 1992. Long-term population studies of seabirds. Trends in $757 \quad$ Ecology and Evolution 7(4): 111-114. 
759 Table 1. Breeding and recruitment overview of numbers and percentages of individual yellow-

760 eyed penguins marked between 1981 and 2003 at Boulder Beach, Otago Peninsula, New Zealand $761 \quad(\mathrm{n}=2147)$.

\begin{tabular}{lcc}
\hline & Number & Percent \\
\hline Marked as chick or juvenile at Boulder Beach & 2147 & \\
Marked chicks that were never resighted & 1546 & 72.0 \\
Marked chicks that were resighted under 2 years & 601 & 28.0 \\
Survived to adulthood (2 years) & 441 & 20.5 \\
$\quad$ Sighted at Boulder Beach & 370 & 17.2 \\
$\quad$ Sighted elsewhere & 71 & 3.3 \\
Attempted breeding at Boulder Beach & 264 & 12.3 \\
Fledged offspring at Boulder Beach & 219 & 10.2 \\
Fledged first-generation offspring that recruited & 124 & 5.8 \\
Fledged successful first-generation offspring & 102 & 4.8 \\
\hline
\end{tabular}


764 Table 2. Mean LRS, number of recruits, number of recruits that bred successfully, lifespan, age-

765 at-first-breeding, breeding lifespan, number of breeding attempts and number of mates of

766 founding generation female $(\mathrm{n}=62)$ and male $(\mathrm{n}=68)$ yellow-eyed penguins breeding at

767 Boulder Beach, New Zealand. (Var= variance; se = standard error; $\min =$ minimum; med =

768 median; $\max =$ maximum).

\begin{tabular}{|c|c|c|c|c|c|c|}
\hline Variable & mean & var & se & $\min$ & med & $\overline{\max }$ \\
\hline & \multicolumn{6}{|c|}{ FEMALES } \\
\hline LRS & 6.82 & 33.8 & 0.74 & 0 & 6 & 24 \\
\hline Recruits & 2.24 & 5.01 & 0.28 & 0 & 2 & 9 \\
\hline Successful recruits & 1.52 & 2.71 & 0.21 & 0 & 1 & 7 \\
\hline Lifespan (years) & 9.44 & 32.77 & 0.73 & 2 & 7.5 & 24 \\
\hline Age at first breeding & 3.60 & 3.16 & 0.23 & 2 & 3 & 12 \\
\hline Breeding lifespan (years) & 5.84 & 26.69 & 0.66 & 0 & 4 & 17 \\
\hline Breeding attempts & 5.79 & 17.74 & 0.53 & 1 & 4.5 & 16 \\
\hline \multirow[t]{2}{*}{ Total mates } & 2.03 & 1.57 & 0.16 & 1 & 2 & 7 \\
\hline & \multicolumn{6}{|c|}{$M A L E S$} \\
\hline LRS & 5.07 & 22.07 & 0.57 & 0 & 4 & 23 \\
\hline Recruits & 1.38 & 2.81 & 0.20 & 0 & 1 & 6 \\
\hline Successful recruits & 0.81 & 1.29 & 0.14 & 0 & 0 & 5 \\
\hline Lifespan (years) & 8.87 & 25.3 & 0.61 & 2 & 8 & 21 \\
\hline Age at first breeding & 4.09 & 3.48 & 0.23 & 2 & 3 & 11 \\
\hline Breeding lifespan (years) & 4.78 & 21.7 & 0.56 & 0 & 3 & 18 \\
\hline Breeding attempts & 4.78 & 11.60 & 0.41 & 1 & 4 & 14 \\
\hline Total mates & 1.93 & 1.32 & 0.14 & 1 & 2 & 6 \\
\hline
\end{tabular}


770 Table 3. Model-averaged generalised linear mixed effects model of lifetime reproductive success

771 (LRS) and life-history parameters of 130 founding generation yellow-eyed penguins $(n=809$

772 breeding attempts) that were marked at Boulder Beach, New Zealand between 1981 and 2003

773 (All non-binary data are standardised to have mean $=0$ and $\mathrm{SD}=1$ ).

774

\begin{tabular}{|c|c|c|c|c|}
\hline Coefficients & Estimate & SE & $\begin{array}{c}95 \% \\
\text { Confidence } \\
\text { Interval }\end{array}$ & $\begin{array}{c}\text { Relative } \\
\text { Importance }\end{array}$ \\
\hline$(\text { Intercept })^{*}$ & 2.02 & 0.04 & $(1.94,2.09)$ & - \\
\hline Sex $(\text { Male })^{\natural}$ & -0.16 & 0.04 & $(-0.25,-0.08)$ & 1.00 \\
\hline $\mathrm{z}(\text { Age at first breeding })^{1}$ & -0.14 & 0.04 & $(-0.21,-0.07)$ & 1.00 \\
\hline 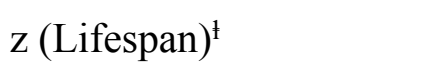 & 0.61 & 0.03 & $(0.55,0.68)$ & 1.00 \\
\hline Sex (Male): z (Lifespan) & 0.01 & 0.03 & $(-0.07,0.13)$ & 0.24 \\
\hline z Total Mates & -0.004 & 0.02 & $(-0.08,0.04)$ & 0.23 \\
\hline
\end{tabular}

*Sex (Female) is the reference category

$776{ }^{\ddagger}$ Significant results

Model statement: glmer(LRS $\sim$ zLifespan + zAgeatfirstbreeding + zTotalmates + factor(Sex $)+$ factor(Sex):zAgeatfirstbreeding + factor(Sex):zLifespan + (1|Matecode) 
782 Table 4. Model-averaged generalised linear mixed-effects model of lifetime reproductive 783 success in yellow-eyed penguins marked at Boulder Beach between 1981 and 2003, including 784 breeder quality as well as (All non-binary data are standardised to have mean $=0$ and $\mathrm{SD}=1$ ).

785

\begin{tabular}{|c|c|c|c|c|}
\hline Coefficients & Estimate & SE & $\begin{array}{c}95 \% \\
\text { Confidence } \\
\text { Interval }\end{array}$ & $\begin{array}{c}\text { Relative } \\
\text { Importance }\end{array}$ \\
\hline$(\text { Intercept })^{*}$ & 1.84 & 0.04 & $(1.77,1.91)$ & - \\
\hline Breeder quality (higher-quality) ${ }^{\ddagger}$ & 0.40 & 0.06 & $(0.29,0.51)$ & 1.00 \\
\hline $\mathrm{z}(\text { Age at first breeding })^{\natural}$ & -0.10 & 0.03 & $(-0.15,-0.05)$ & 1.00 \\
\hline$z(\text { Lifespan })^{\ddagger}$ & 0.60 & 0.04 & $(0.52,0.67)$ & 1.00 \\
\hline Breeder quality (higher-quality):z(Lifespan) ${ }^{\natural}$ & -0.21 & 0.05 & $(-0.31,-0.11)$ & 1.00 \\
\hline $\mathrm{z}$ (Total mates) & 0.01 & 0.02 & $(-0.03,0.08)$ & 0.34 \\
\hline
\end{tabular}

*Breeder quality (lower-quality) is the reference category

${ }^{\ddagger}$ Significant results

788

789

Model statement: glmer(LRS $\sim z($ Lifespan $)+z($ Ageatfirstbreeding $)+z$ (Totalmates $)+$

790 factor(BreederType) + factor(BreederType):z(Ageatfirstbreeding) +

791 factor(BreederType):z(Lifespan) + (1|Matecode)

792 
793 Table 5. Mean LRS, number of first-generation offspring, number of first-generation offspring that bred 794 successfully, lifespan, age-at-first-breeding, breeding lifespan, number of breeding attempts and number 795 of mates of ordinary and high-quality yellow-eyed penguins breeding at Boulder Beach, New Zealand.

796 (Var = variance; $s e=$ standard error; $\min =$ minimum; med $=$ median; $\max =$ maximum $)$. Continued 797 overleaf.

\begin{tabular}{lcccccc}
\hline Variable & mean & var & se & min & med & max \\
\hline \multirow{7}{*}{ LRS } & \multicolumn{7}{c}{ Females } & (ordinary & breeders, $\boldsymbol{n}=46)$ \\
\cline { 2 - 7 } Recruits & 4.37 & 14.06 & 0.55 & 0 & 4 & 17 \\
Successful recruits & 1.33 & 2.27 & 0.22 & 0 & 1 & 5 \\
Lifespan (years) & 0.83 & 1.12 & 0.16 & 0 & 0 & 4 \\
Age at first breeding & 7.48 & 23.63 & 0.72 & 2 & 6 & 22 \\
Breeding lifespan (years) & 3.30 & 2.57 & 0.24 & 2 & 3 & 12 \\
Breeding attempts & 4.17 & 20.46 & 0.67 & 0 & 3 & 17 \\
Total mates & 4.15 & 9.51 & 0.45 & 1 & 3.5 & 13 \\
& 1.80 & 1.36 & 0.17 & 1 & 1 & 7
\end{tabular}

\begin{tabular}{lcccccc}
\hline & \multicolumn{7}{c}{ Females (high-quality breeders, $\boldsymbol{n}=\mathbf{1 6}$ ) } \\
\cline { 2 - 6 } LRS & 13.88 & 23.85 & 1.22 & 7 & 12 & 24 \\
Recruits & 4.88 & 3.58 & 0.47 & 2 & 4.5 & 9 \\
Successful recruits & 3.5 & 2 & 0.35 & 1 & 3 & 7 \\
Lifespan (years) & 15.06 & 16.86 & 1.03 & 7 & 16 & 24 \\
Age at first breeding & 4.44 & 4.13 & 0.51 & 3 & 4 & 10 \\
Breeding lifespan (years) & 10.63 & 14.25 & 0.94 & 4 & 9.5 & 17 \\
Breeding attempts & 10.5 & 11.73 & 0.86 & 5 & 9 & 16 \\
Total mates & 2.69 & 1.70 & 0.33 & 1 & 3 & 5 \\
\hline & & Males (ordinary breeders, $\boldsymbol{n}=\mathbf{5 2})$ & \\
LRS & 3.42 & 9.82 & 0.43 & 0 & 2 & 14 \\
Recruits & 0.75 & 1.09 & 0.14 & 0 & 0 & 4 \\
Successful recruits & 0.33 & 0.30 & 0.08 & 0 & 0 & 2 \\
Lifespan (years) & 7.58 & 19.31 & 0.61 & 2 & 6 & 19 \\
Age at first breeding & 4.04 & 3.45 & 0.26 & 2 & 3 & 11 \\
Breeding lifespan (years) & 3.54 & 15.43 & 0.54 & 0 & 2.5 & 14 \\
Breeding attempts & 3.87 & 9.06 & 0.42 & 1 & 3 & 12 \\
Total mates & 1.83 & 1.52 & 0.17 & 1 & 1 & 6 \\
\hline
\end{tabular}

Males (high-quality breeders, $n=16$ )

LRS

$\begin{array}{llllll}10.44 & 25.06 & 1.25 & 5 & 8.5 & 23\end{array}$




\begin{tabular}{lcccccc} 
Recruits & 3.44 & 2.93 & 0.43 & 1 & 3 & 6 \\
Successful recruits & 2.38 & 1.32 & 0.29 & 1 & 2 & 5 \\
Lifespan (years) & 13.06 & 22.6 & 1.19 & 8 & 12 & 21 \\
Age at first breeding & 4.25 & 3.8 & 0.49 & 2 & 3.5 & 9 \\
Breeding lifespan (years) & 8.81 & 21.63 & 1.16 & 3 & 6.5 & 18 \\
Breeding attempts & 7.75 & 8.73 & 0.74 & 4 & 7 & 14 \\
Total mates & 2.25 & 0.6 & 0.19 & 1 & 2 & 4 \\
\hline
\end{tabular}


799 Table 6. Comparison of LRS and maximum number of young fledged by individuals of five 800 different bird species for males and females (where data were available from Coulson 1988;

801 Mills 1989; Dann and Cullen 1990; Korpimäki 1992; Krüger and Lindström 2001; Garamszegi 802 et al. 2004).

803

\begin{tabular}{|c|c|c|c|c|}
\hline Species & $\begin{array}{c}\text { LRS } \\
\text { (Female) }\end{array}$ & $\begin{array}{c}\text { LRS } \\
\text { (Male) }\end{array}$ & $\begin{array}{c}\text { Max. } \\
\text { fledged } \\
\text { (Female) }\end{array}$ & $\begin{array}{c}\text { Max. } \\
\text { fledged } \\
\text { (Male) }\end{array}$ \\
\hline $\begin{array}{l}\text { Yellow-eyed penguin } \\
\text { (Megadyptes antipodes) }\end{array}$ & 6.82 & 5.07 & 24 & 23 \\
\hline $\begin{array}{l}\text { Black-legged kittiwake } \\
\text { (Rissa tridactyla) }\end{array}$ & 6.93 & 7.41 & - & - \\
\hline $\begin{array}{l}\text { Red-billed gull } \\
\text { (Larus novaehollandiae) }\end{array}$ & 3.4 & 3 & 26 & 28 \\
\hline $\begin{array}{l}\text { Little penguin } \\
\text { (Eudyptula minor) }\end{array}$ & 2.28 & 2.13 & 35 & 44 \\
\hline $\begin{array}{l}\text { Tengmalm's owl } \\
\text { (Aegolius funereus) }\end{array}$ & - & 5.2 & - & 26 \\
\hline $\begin{array}{l}\text { Common buzzard } \\
\text { (Buteo buteo) }\end{array}$ & 3.48 & 2.72 & 20 & 20 \\
\hline $\begin{array}{l}\text { Collared flycatcher } \\
\text { (Ficedula albicollis) }\end{array}$ & 5.18 & - & - & - \\
\hline
\end{tabular}

804

805

806 


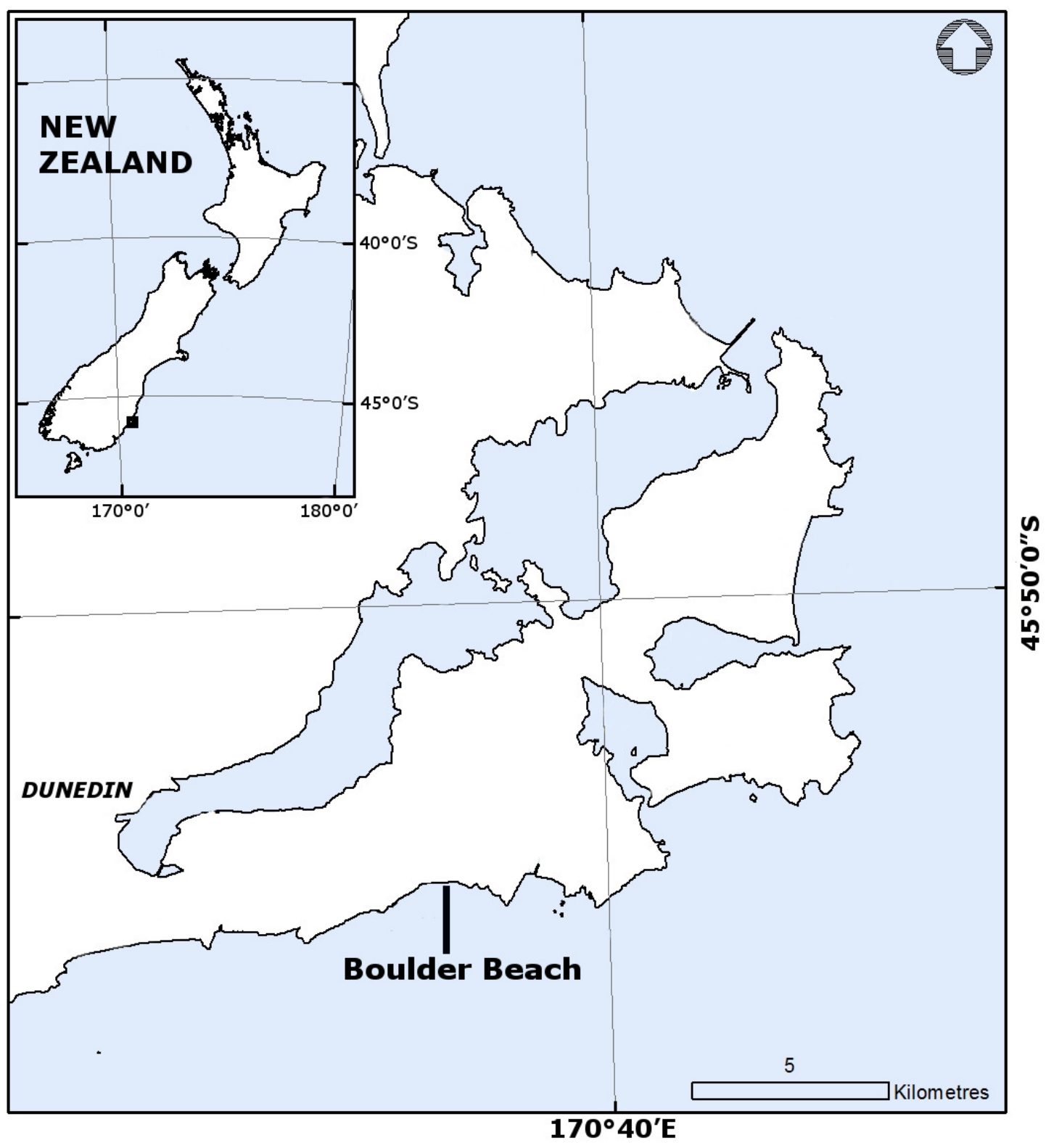

808

809 Figure 1. Map showing the location of Boulder Beach on the Otago Peninsula, Dunedin, New 810 Zealand. 


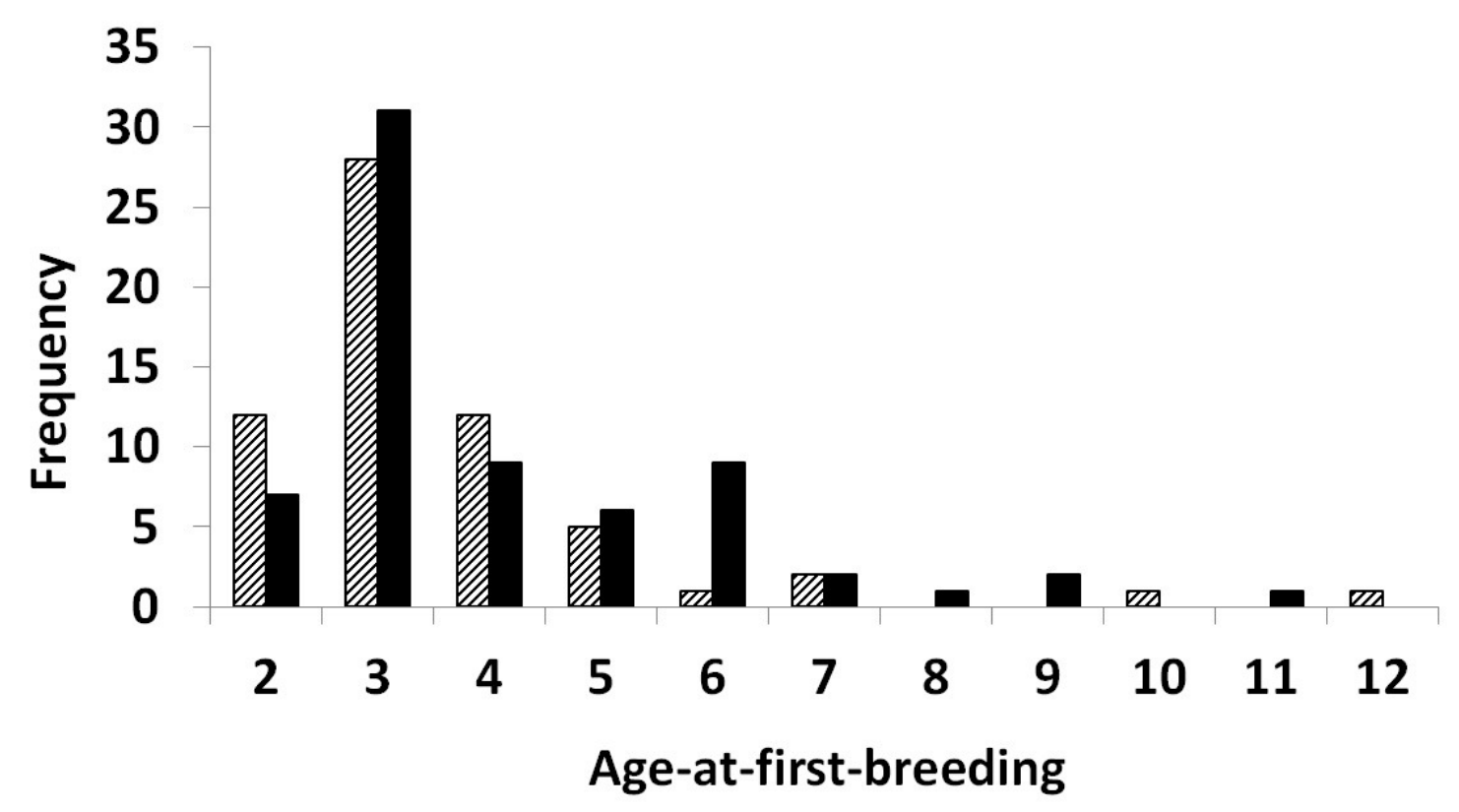

811

812 Figure 2. Age-at-first-breeding of female (striped, $n=62$ ) and male (black, $n=68$ ) yellow-eyed 813 penguins with complete life histories that bred at Boulder Beach, Dunedin, New Zealand. 


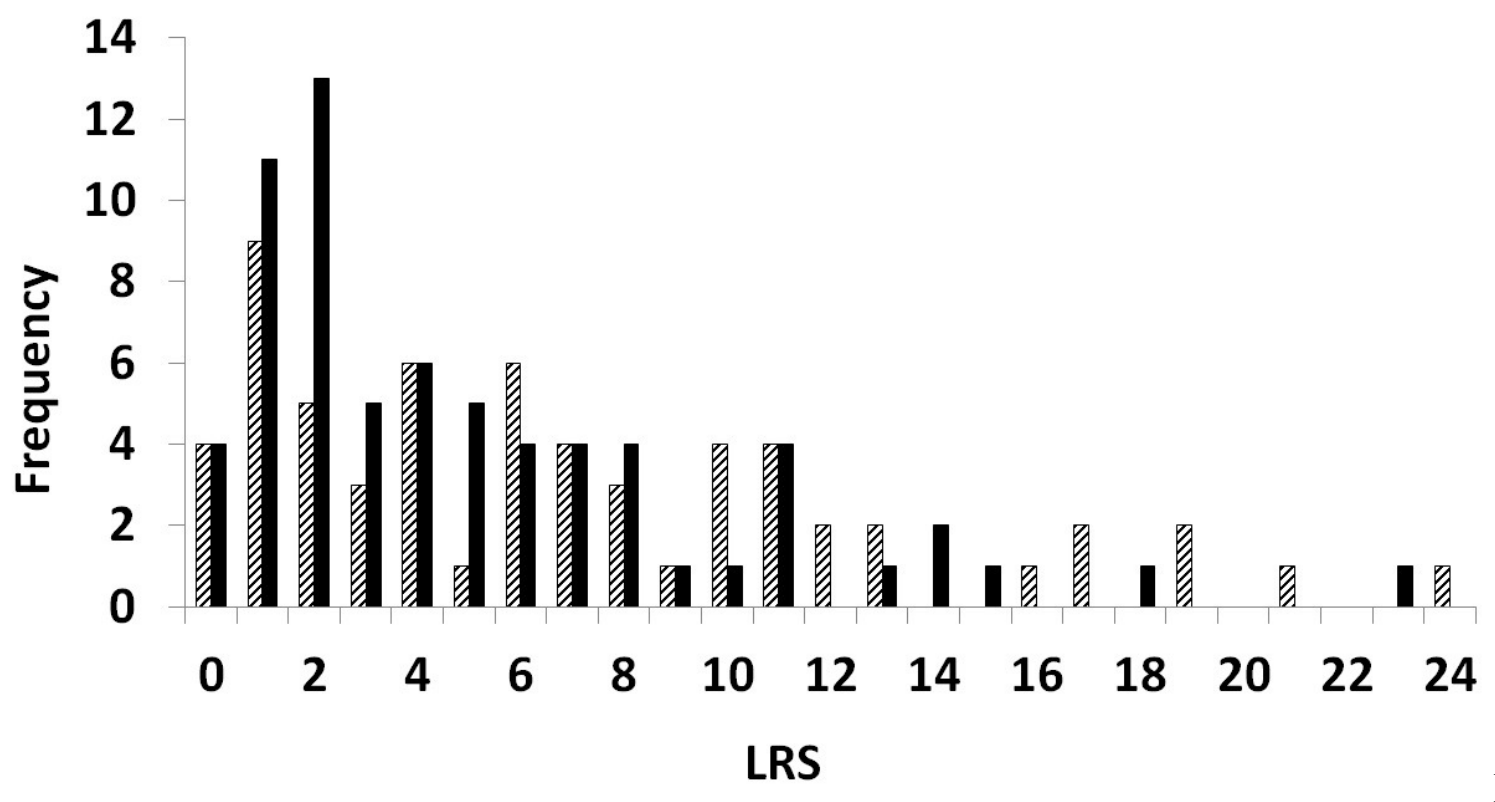

816 3. Frequencies of the total number of chicks fledged (lifetime reproductive success, LRS) by

817 female (striped, $\mathrm{n}=62$ ) and male (black, $\mathrm{n}=68$ ) yellow-eyed penguins with complete life

818 histories that bred at Boulder Beach, New Zealand. 
819

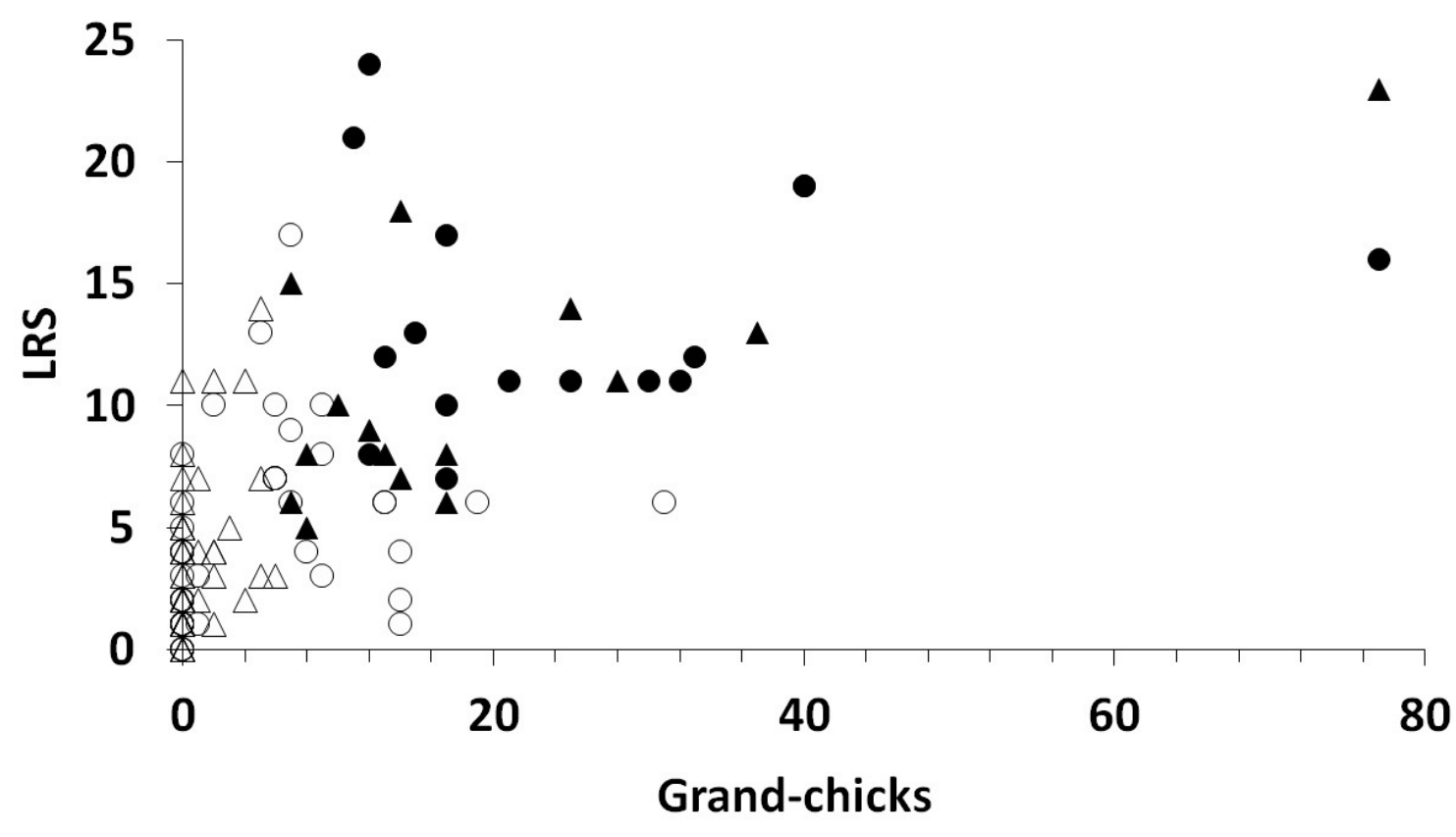

820

821

822 Figure 4. The relationship between lifetime reproductive success (LRS) and the production of 823 second-generation offspring (grand-offspring) for female (filled dots = "high-quality breeder", 824 empty dots = "low-quality breeder") and male (filled triangles = "high-quality breeder", open 825 triangles = "low-quality breeder") yellow-eyed penguins with complete life histories that bred at 826 Boulder Beach, New Zealand. 